\title{
Tetracycline-Inducible Gene Expression in Conditionally Immortalized Mouse Podocytes
}

\author{
Hiroshi Kajiyama $^{a} \quad$ Steve Titus $^{b} \quad$ Christopher P. Austin $^{b}$ Kathleen Chiotos ${ }^{a}$ \\ Takayuki Matsumoto $^{a}$ Toru Sakairi $^{a}$ Jeffrey B. Kopp ${ }^{a}$ \\ ${ }^{a}$ Kidney Disease Section, Kidney Disease Branch, National Institute of Diabetes, Digestive and Kidney Diseases, \\ and ${ }^{b} \mathrm{NIH}$-Chemical Genomics Center, National Human Genome Research Institute, National Institutes of Health, \\ Department of Health and Human Services, Bethesda, Md., USA
}

\section{Key Words}

Tetracycline-inducible system $\cdot$ Conditional

immortalization $\cdot$ Transcription $\cdot$ Gene of interest

\begin{abstract}
Background: Conditionally immortalized podocytes are valuable research tools but are difficult to efficiently transfect and do not provide graded transgene expression. Methods: Conditionally immortalized mouse podocyte cell lines were established employing a tetracycline-inducible system. Glomerular cells, isolated from transgenic mice bearing two transgenes, NPHS2-reverse tetracycline-controlled transactivator, rtTA (A transgene) and $\mathrm{H} 2$ - $K b$-thermosensitive SV40 T, ts58A (I transgene), were cloned. One clone (AI podocytes) expressing WT1 and synaptopodin was transfected with pBI-EGFP (enhanced green fluorescent protein, $\mathrm{G}$ transgene) and separately with ptTS-Neo (transcriptional suppressor, $\mathrm{T}$ transgene) to produce stable transformants, AIG podocytes and AIT podocytes. Results: AIG podocytes expressed EGFP at 33 and $37^{\circ} \mathrm{C}$ after doxycycline treatment, and retained podocin and rtTA mRNA expression and temperature-sensitive growth regulation. AIT podocytes, transiently transfected with luciferase-BI-EGFP (LG transgene),
\end{abstract}

showed reduced background expression of EGFP and luciferase in the absence of doxycycline. In AITLG podocytes, generated by stable transfection of AIT podocytes with the LG transgene, luciferase expression was tightly regulated by doxycycline in a time- and concentration-dependent manner both at 33 and $37^{\circ} \mathrm{C}$, although background expression was not entirely eliminated. These podocytes retained temperature-sensitive growth regulation and expression of podocyte differentiation markers. Conclusion: Mouse podocytes expressed tetracycline-induced transgenes efficiently while retaining differentiation markers.

Copyright $\odot 2008$ S. Karger AG, Basel

\section{Introduction}

Podocytes play a critical role in generating and maintaining glomerular structure and function [1]. Conditionally immortalized cultured podocytes derived from mice [2] and humans [3] have been highly useful in exploring podocyte biology. These podocyte lines bear a thermosensitive SV40 T antigen, which allows cells to grow at $33^{\circ} \mathrm{C}$ (permissive conditions) and to differentiate at $37^{\circ} \mathrm{C}$ (non-permissive conditions). One limitation of

\section{KARGER}

(C) 2008 S. Karger AG, Basel

Fax +41613061234

E-Mail karger@karger.ch

www.karger.com
Accessible online at:

www.karger.com/ajn
Jeffrey B. Kopp

10 Center Drive, NIH

Bethesda, MD 20892-1268 (USA)

Tel. +1 301594 3403, Fax +1 3014020014

E-Mail jbkopp@nih.gov 
these cell lines is that most approaches to transient transfection have limited success in quiescent cells, and expression of the transfected gene is lost when the cells are cultured under non-permissive conditions to allow differentiation [4]. Another limitation of transient transfection is the difficulty of generating graded levels of transient expression. In order to overcome these limitations, we have established a series of conditionally immortalized podocyte cell lines using a tetracycline-inducible system with the reverse tetracycline-transactivator protein (rtTA) [5].

\section{Materials and Methods}

\section{Transgenic Mice and Genotyping}

We previously reported bitransgenic mice bearing the NPHS2rtTA (A) and TetO-LacZ constructs [6]. We crossbred $\mathrm{A}^{+/-}$mice with homozygous Immortomouse $\left(\mathrm{I}^{+/+}\right.$; Charles River Laboratories, Wilmington, Mass., USA), harboring tsA58, thermosensitive SV40 large T antigen [7]. Glomeruli were isolated from bitransgenic offspring with the $\mathrm{A}^{+/-} \mathrm{I}^{+/-}$genotype. Animal care conformed to the National Institutes of Health Guide for the Care and Use of Laboratory Animals and was approved by the National Institutes of Diabetes and Digestive and Kidney Diseases Animal Care and Use Committee.

For genotyping, PCR was done with Taq PCR Master Mix Kit (Qiagen, Valencia, Calif., USA) for the $A$ gene as previously reported [6]. PCR for the I gene employed a forward primer, $5^{\prime}$-AGC GCT TGT GTC GCC ATT GTA TTC-3', and a reverse primer, 5'-GTC ACA CCA CAG AAG TAA GGT TCC-3', yielding a 1,000 -bp product. PCR cycle parameters for the $I$ gene were $94^{\circ} \mathrm{C}$ for $4 \mathrm{~min}$ for $1 \mathrm{cycle}$, then 30 cycles of $94^{\circ} \mathrm{C}$ for $30 \mathrm{~s}, 58^{\circ} \mathrm{C}$ for $1 \mathrm{~min}$, and $72^{\circ} \mathrm{C} 1 \mathrm{~min} 30 \mathrm{~s}$, with a final extension at $72^{\circ} \mathrm{C}$ for 5 min.

\section{Glomerular Isolation and Cloning}

Glomeruli were isolated by sieving [8]. Isolated glomeruli were resuspended in $5 \mathrm{ml}$ of RPMI 1640 (BioSource, Rockville, Md., USA) with 100 units $/ \mathrm{ml}$ of penicillin G sodium, $100 \mu \mathrm{g} / \mathrm{ml}$ of streptomycin sulfate (Invitrogen, Carlsbad, Calif., USA), 10\% tetracycline-deficient fetal bovine serum (Clontech, Mountain View, Calif., USA) and $30 \mathrm{U} / \mathrm{ml}$ of mouse interferon- $\gamma$ (Cell Sciences, Canton, Mass., USA). Glomeruli were placed in 2 wells $(2.5 \mathrm{ml} /$ well) in BD BioCoat collagen I 6-well plate (BD Biosciences, San Jose, Calif., USA), and cultured for $6-7$ days at $37^{\circ} \mathrm{C}$. Outgrowing cells were trypsinized, filtered with $40 \mu \mathrm{m}$ cell strainer to remove glomeruli, and were cloned by limiting dilution.

\section{Phenotyping of Clones}

To examine podocyte marker expression, clones cultured both at 33 and $37^{\circ} \mathrm{C}$ with or without doxycyline $(4 \mu \mathrm{g} / \mathrm{ml})$ for $48 \mathrm{~h}$, were analyzed by indirect immunofluorescent staining for WT1, synaptopodin and podocin, and by reverse transcriptase (RT)-PCR for podocin rtTA, nephrin and GAPDH mRNA. Cells cultured on BD BioCoat Collagen I glass coverslips or $100-\mathrm{mm}$ culture dishes were fixed with $2 \%$ paraformaldehyde (Sigma, St. Louis, Mo.,
USA) and $4 \%$ sucrose for $5 \mathrm{~min}$ at room temperature, permeabilized for 10 min with $0.3 \%$ Triton X-100 in phosphate-buffered saline (PBS) without calcium or magnesium, and incubated for an hour in blocking solution (2\% fetal bovine serum, $2 \%$ bovine serum albumin, $0.2 \%$ gelatin in PBS). Primary antibodies included 1:100 dilution of WT1 polyclonal antibody (C-19; Santa Cruz Biotechnology, Santa Cruz, Calif., USA), $1 \times$ hybridoma culture supernatant of synaptopodin monoclonal antibody (G1D4; Research Diagnostics, Flanders, N.J., USA), and 1:100 dilution of rabbit polyclonal mouse podocin antibody (gift from Dr. Peter Mundel). Alexa Fluor 488 goat anti-rabbit IgG $(\mathrm{H}+\mathrm{L})$ and Alexa Fluor 488 goat anti-mouse $\operatorname{IgG}(\mathrm{H}+\mathrm{L}$; Invitrogen) were used at 1:1,500 dilution as secondary antibodies. Stained cells were mounted in 20\% Mowiol 4-88 reagent (EMD Biosciences, La Jolla, Calif., USA) or ProLong Gold antifade reagent (Invitrogen), and were observed using Leica DMRXE microscope (Leica, Microsystems CMS GmbH, Wetzlar, Germany). Signals were captured as digital images with MicroPublisher 5.0 and QCapture software (Qimaging, Burnaby, B.C., Canada).

Total RNA was purified from each podocyte clone using the RNeasy mini kit and RNase-free DNase set (Qiagen). RNA concentration was measured by an ND-1000 spectrophotometer (NanoDrop Technologies, Wilmington, Del., USA). RT-PCR was performed using the OneStep RT-PCR kit (Qiagen). Primers for podocin were as follows: forward primer $5^{\prime}$-GAA AGG AAG AGC ATT GCC CAA G-3' and reverse primer 5'-TGT GGA CAG CGA CTG AAG AGT GTG-3', yielding a 288-bp product. RT-PCR parameters are $50^{\circ} \mathrm{C}$ for $30 \mathrm{~min}$ for $\mathrm{RT}, 95^{\circ} \mathrm{C}$ for $15 \mathrm{~min}$ for inactivation of RT, then 40 cycles of $95^{\circ} \mathrm{C}$ for $30 \mathrm{~s}, 58^{\circ} \mathrm{C}$ for $30 \mathrm{~s}, 72^{\circ} \mathrm{C}$ for $30 \mathrm{~s}$, followed by $72^{\circ} \mathrm{C}$ for $10 \mathrm{~min}$. The primers for rtTA were: forward 5'-GAA CAA CGC CAA GTC ATT CCG-3' and reverse 5'-TAC GCA GCC CAG TGT AAA GTG G-3' yielding a 196-bp product. RT-PCR parameters were $50^{\circ} \mathrm{C}$ for $30 \mathrm{~min}$ for RT, 35 cycles of $95^{\circ} \mathrm{C}$ for $15 \mathrm{~min}$ for RT inactivation, then 35 cycles of $95^{\circ} \mathrm{C}$ for $30 \mathrm{~s}, 58.2^{\circ} \mathrm{C}$ for $30 \mathrm{~s}$, and $72^{\circ} \mathrm{C}$ for $30 \mathrm{~s}$, with $72^{\circ} \mathrm{C}$ for 10 $\mathrm{min}$ as a final extension. Nephrin forward and reverse primers were used as previously reported [9], with PCR conditions $50^{\circ} \mathrm{C}$ for $30 \mathrm{~min}$ for $\mathrm{RT}, 95^{\circ} \mathrm{C}$ for $15 \mathrm{~min}$ for RT inactivation, then 35 cycles of $95^{\circ} \mathrm{C}$ for $30 \mathrm{~s}, 55.6^{\circ} \mathrm{C}$ for $30 \mathrm{~s}, 72^{\circ} \mathrm{C}$ for $30 \mathrm{~s}$, with a final extension of $72^{\circ} \mathrm{C}$ for $10 \mathrm{~min}$. GAPDH forward and reverse primers were used as previously reported [9], and RT-PCR parameters were $50^{\circ} \mathrm{C}$ for $30 \mathrm{~min}$ for $\mathrm{RT}, 95^{\circ} \mathrm{C}$ for $15 \mathrm{~min}$ for RT inactivation, then 30 cycles of $95^{\circ} \mathrm{C}$ for $30 \mathrm{~s}, 58.2^{\circ} \mathrm{C}$ for $30 \mathrm{~s}, 72^{\circ} \mathrm{C}$ for $30 \mathrm{~s}$, with final extension of $72^{\circ} \mathrm{C}$ for $10 \mathrm{~min}$. Total RNA extracted from the kidneys of an $A^{+/-}$mouse was used as a positive control, and total RNA from the murine mesangial cell line, MES13, was used as a negative control.

Stable Transfection of the Reporter Gene Construct

The podocyte clone AI1-1P4G5 was selected based on high expression of WT-1 and synaptopodin for transfection from among 29 clones obtained. pBI-EGFP (gift of Dr. Bert Vogelstein) was linearized using Ahd1 (New England Biolabs, Beverly, Mass., USA). Podocytes $\left(6 \times 10^{4} /\right.$ well $)$ were plated on a collagen I-coated 6 -well plate using the glomerular culture medium described above. On the following day, AI or AIT podocytes in each well were transfected with $4 \mu \mathrm{g}$ of DNA consisting of pBI-EGFP or Gaussia luciferase-subcloned into pBI-EGFP and the Linear Hygromycin Marker plasmid (Clontech) with 10:1 ratio, or ptTSNeo alone, using the FuGENE 6 Transfection Reagent (Roche Di- 
agnostics). The ratio of Fugene 6:DNA was 3:2. Hygromycin B (Invitrogen) or Geneticin (Invitrogen) at a concentration of 50$100 \mu \mathrm{g} / \mathrm{ml}$ were added to the culture medium $48-72 \mathrm{~h}$ after transfection. Culture medium including $50-100 \mu \mathrm{g} / \mathrm{ml}$ of hygromycin B or Geneticin was changed every 4th day. Surviving colonies were selected using cloning cylinders and passaged to BD BioCoat collagen I $25-\mathrm{cm}^{2}$ flask (Becton Dickinson Discovery Labware).

\section{Culture and Phenotyping of AIG Podocytes}

One of the AIG podocyte clones, AI1G10, was arbitrarily chosen out of 16 clones obtained. These cells were cultured on collagen I cell ware under the permissive condition. When cells reached $\sim 75 \%$ confluence, $1 \mu \mathrm{g} / \mathrm{ml}$ of doxycycline was added. Cells were transferred to the non-permissive temperature when cells reached $80-90 \%$ confluence, and cultured for at least 7 days without medium change, then exposed to doxycycline $(1 \mu \mathrm{g} / \mathrm{ml})$. Cells were observed $48 \mathrm{~h}$ after doxycycline treatment with Axiovert $405 \mathrm{M}$ (Carl Zeiss MicroImaging, Thornwood, N.Y., USA). The EGFP signal was captured by Hamamatsu-C4742-95 (Hamamatsu, Hamamatsu, Japan), and processed using IP-lab 3.95 (BD Biosciences Bioimaging, Rockville, Md., USA) and Photoshop version 3.0 (Adobe Systems, San Jose, Calif., USA). In time course and concentration-ranging studies carried out under permissive conditions, AIG podocytes were treated with doxycycline $(0.01-4 \mu \mathrm{g} /$ $\mathrm{ml}$ ) for different time intervals (0-72 h), and GFP expression was quantitated using the Acumen Explorer Laser Scanning Plate Cytometer (TTP LabTech, Cambridge, Mass., USA). Objects were excited with a $488-\mathrm{nm}$ laser at $4 \mathrm{~mW}$ of power and emission was detected with the 500-520 nM emission photomultiplier tube (PMT) set at $550 \mathrm{~V}$. The plate was scanned with $1 \times 4 \mu \mathrm{m}$ sampling and objects ranging in size from 25 to $250 \mu \mathrm{m}$ were collected.

\section{Comparison of AI and AIT Podocytes Leakiness and}

Inducibility

$6 \times 10^{4}$ cells/well of AI podocytes or AIT podocytes were plated on collagen I-coated 6-well plates at the permissive temperature. On the following day, Gaussia luciferase-pBI-EGFP was transfected using FuGENE6, and cells were subsequently treated with 0 or $10 \mu \mathrm{g} / \mathrm{ml}$ of doxycycline. After $48 \mathrm{~h}$, EGFP signal was captured and Gaussia luciferase activity in the supernatant was detected by Gaussia luciferase assay kit (New England Biolabs, Ipswich, Mass., USA).

Time- and Dose-Ranging Study in AITLG Podocytes

AITLG podocytes were plated on collagen I-coated 6-well plates for EGFP assay or 24-well plates for luciferase assay at permissive and non-permissive temperatures. When confluence reached $70-80 \%$, doxycycline $(0,0.01,0.03,0.11,0.33,1$ and $3 \mu \mathrm{g} /$ $\mathrm{ml}$ ) was added at the permissive temperature, and supernatant was collected after $48 \mathrm{~h}$ and stored at $-20^{\circ} \mathrm{C}$. For the time-ranging study at the permissive temperature, podocytes were treated with $1 \mu \mathrm{g} / \mathrm{ml}$ doxycycline and supernatant was collected at the $0-, 6-$, 12-, 24-, 48-, 72- and 96-hour time points and stored at $-20^{\circ} \mathrm{C}$ until tested. At the non-permissive temperature, AITLG podocytes were cultured for 5 days without medium change, and doxycycline $(0,0.11,0.33,1$, and $3 \mu \mathrm{g} / \mathrm{ml})$ was added for the concentration- and $1 \mu \mathrm{g} / \mathrm{ml}$ doxycycline for the time-ranging $(0,12,24$, 48,72 and 96 h) study. EGFP was captured as described above after $48 \mathrm{~h}$ of $1 \mu \mathrm{g} / \mathrm{ml}$ of doxycycline treatment at non-permissive and permissive temperatures.

Tetracycline-Inducible Gene Expression in Podocytes

\section{Western Blotting}

Treated with or without $4 \mu \mathrm{g} / \mathrm{ml}$ of doxycycline for $48 \mathrm{~h}, 33^{\circ} \mathrm{C}$ AITLG podocytes and $37^{\circ} \mathrm{C}$ AITLG podocytes were pelleted and stored at $-80^{\circ} \mathrm{C}$. Cells were lysed with $0.5 \% \mathrm{CHAPS}$ buffer $(20 \mathrm{mM}$ Tris- $\mathrm{HCl}, 500 \mathrm{mM} \mathrm{NaCl}, 0.5 \%$ CHAPS) with protease inhibitor cocktail (Roche Diagnostics, Indianapolis, Ind., USA) and the lysate protein concentration was quantified with BCA protein assay kit (Pierce, Rockford, Ill., USA). Thirty micrograms of lysate per lane was loaded in NuPAGE 4-12\% Bis-Tris Gel (Invitrogen) and electrophoresed under the reducing condition, and transferred to nitrocellulose membranes (Pierce). The membrane was immunoblotted with rabbit poly anti-podocin (1:300 dilution; gift from Dr. Peter Mundel) and Immunopure antibody donkey anti-rabbit peroxidase conjugated (1:10,000; Pierce) for podocin, and the signal was detected by SuperSignal West Dura Extended Duration Substrate (Pierce). After anti-podocin was stripped with Restore Western Blot Stripping Buffer (Pierce), the membrane was reprobed with mouse monoclonal anti- $\beta$-actin (1:10,000 dilution; Sigma) and Immunopure antibody goat anti-mouse peroxidase conjugated $(1: 50,000)$ (Pierce) for $\beta$-actin.

\section{Proliferation Study}

At passage $16,6 \times 10^{4} \mathrm{AIG}$ and AITLG podocytes were plated on collagen I-coated 6-well plates and cultured for 24, 48, 72, 96 , and $120 \mathrm{~h}$. Cells were trypsinized and cell numbers were counted.

\section{Statistical Analysis}

Statistical analysis was performed using PRISM 4.0b (GraphPad Software, San Diego, Calif., USA). Data are presented as mean $\pm \mathrm{SD}$, unless otherwise described. Proliferation data were analyzed by two-way ANOVA with Bonferroni post-testing, using the variables, time and temperature. Unpaired test was used for comparison of 2 groups. $\mathrm{p}<0.05$ was considered to be statistically significant.

\section{Results}

\section{Generating AI, AIG, AIT, and AITLG Podocytes}

Figure 1 summarizes the process of generating podocytes bearing the tetracycline-inducible constructs. Heterozygous podocin-rtTA mice $\left(\mathrm{A}^{+/-}\right)$[6] were mated with the homozygous Immortomouse bearing the temperature-sensitive SV40 T antigen $\left(\mathrm{I}^{+/+}\right)$[7] to generate heterozygous mice $\left(\mathrm{A}^{+/-} \mathrm{I}^{+/-}\right)$. Glomeruli were isolated from $\mathrm{A}^{+/-} \mathrm{I}^{+/-}$mice by sieving, and outgrown cells were subject to limiting dilution to obtain 29 clones. Based on the high expression level of WT-1 and synaptopodin, one clone of AI podocytes was selected for further study (fig. 2a). This AI podocyte cell line was further stably transfected with pBI-EGFP and SV40-Hygro (G), ptTS-Neo (T) and luciferase-pBI-EGFP and SV40-Hygro (LG) to generate AIG, AIT and AITLG podocytes, respectively. 


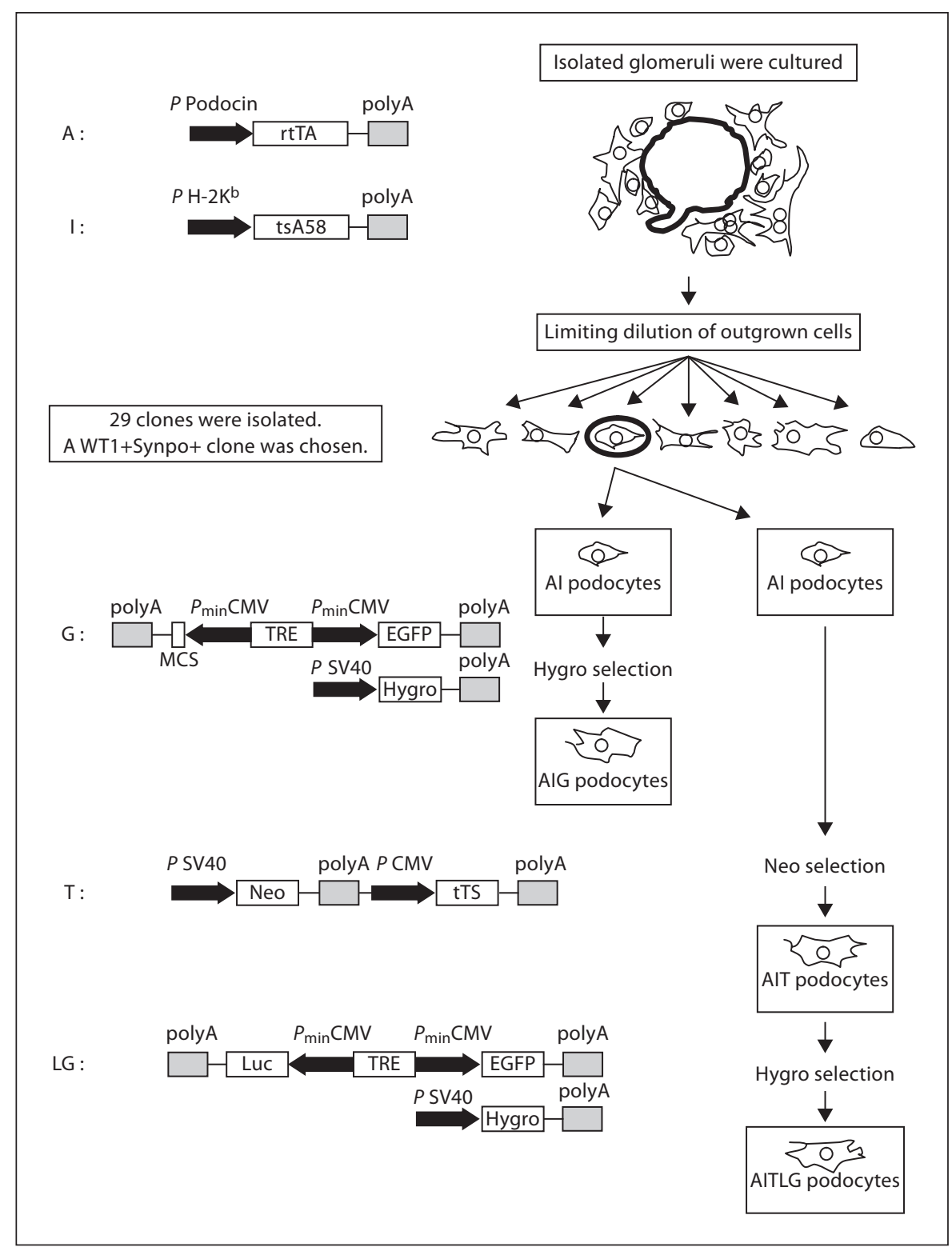

Fig. 1. Schematic representation of transgenes and stable transfection in murine podocytes. The podocytes described here bear up to five transgenes. The A transgene has the reverse tetracycline transactivator protein (rtTA), a chimeric protein which includes a tetracycline-responsive domain and the VP16 activation domain, whose expression is driven by the podocin promoter. In the presence of doxycycline, rtTA initiates transcription from a tetracycline response element (TRE). The I transgene, present in the Immortomouse genome, has a mutated SV40 thermosensitive T antigen (tsA58) driven by the $\mathrm{H}-2 \mathrm{~Kb}$ promoter, which is enhanced by interferon- $\gamma$. ts $\mathrm{A} 58$ is active at $33^{\circ} \mathrm{C}$ and inactivated at $37^{\circ} \mathrm{C}$, and this confers conditional immortalization on the cells. The $\mathrm{G}$ transgene has a TRE which activates transcription from a bidirectional promoter which includes dual cytomegalovirus (CMV) promoter elements. This bidirectional promoter controls expression of enhanced green fluorescent protein (EGFP) as a reporter gene and a functional gene of interest cloned at a multiple cloning site. Gauss- ia luciferase was subcloned into a Nhe1 site in this multiple cloning site to produce LG transgene, expressing both luciferase and EGFP. Another transgene bearing the hygromycin-resistance gene driven by SV40 promoter, which confers hygromycin resistance to facilitate cell selection, was co-transfected with G and LG transgenes. The $\mathrm{T}$ transgene contains the neomycin resistance gene driven by the SV40 promoter and tetracycline-controlled transcriptional suppressor (tTS) driven by the CMV promoter. $\mathrm{tTS}$ is a fusion protein of the Tet-repressor protein (TetR) and KRAB-ABsilencing domain of the Kid-1 protein, and binds the TRE sequence to block background expression in the absence of doxycycline. In the presence of doxycycline, tTS binds doxycycline and dissociates from the TRE, and the doxycycline-bound rtTA binds TRE to induce gene expression. For AIG and AITLG podocytes, this transgenic system results in conditional expression of EGFP (with or without luciferase) when doxycycline is present and the cellular phenotype supports podocin promoter activity. 
Fig. 2. AI podocyte phenotype and induced expression of EGFP in AIG podocytes. a One AI podocyte clone was chosen expressing WT1 at $33^{\circ} \mathrm{C}$ and synaptopodin at $37^{\circ} \mathrm{C}$. WT1 was expressed in a characteristic nuclear pattern, and synaptopodin was expressed along cytoskeleton filaments and focal accumulations. Compared with a fusiform shape at $33^{\circ} \mathrm{C}$, podocytes at $37^{\circ} \mathrm{C}$ exhibited a flatter, enlarged shape. Indirect immunofluorescent staining. $\times 400$. $\mathbf{b}$ EGFP expression was induced in AIG podocytes at 33 and $37^{\circ} \mathrm{C}$ after 48 hour exposure to $1 \mu \mathrm{g} / \mathrm{ml}$ of doxycycline (DOX). Shown are merged phase contrast images and fluorescent images. $\times 100$. c EGFP expression in AIG podocytes cultured at $33^{\circ} \mathrm{C}$ was quantitated in a concentration-response study after $48 \mathrm{~h}$ (left panel) and in a time-course study using $3 \mu \mathrm{g} /$ $\mathrm{ml}$ of doxycycline (right panel; $\mathrm{n}=3$; mean $\pm \mathrm{SE}$ ).
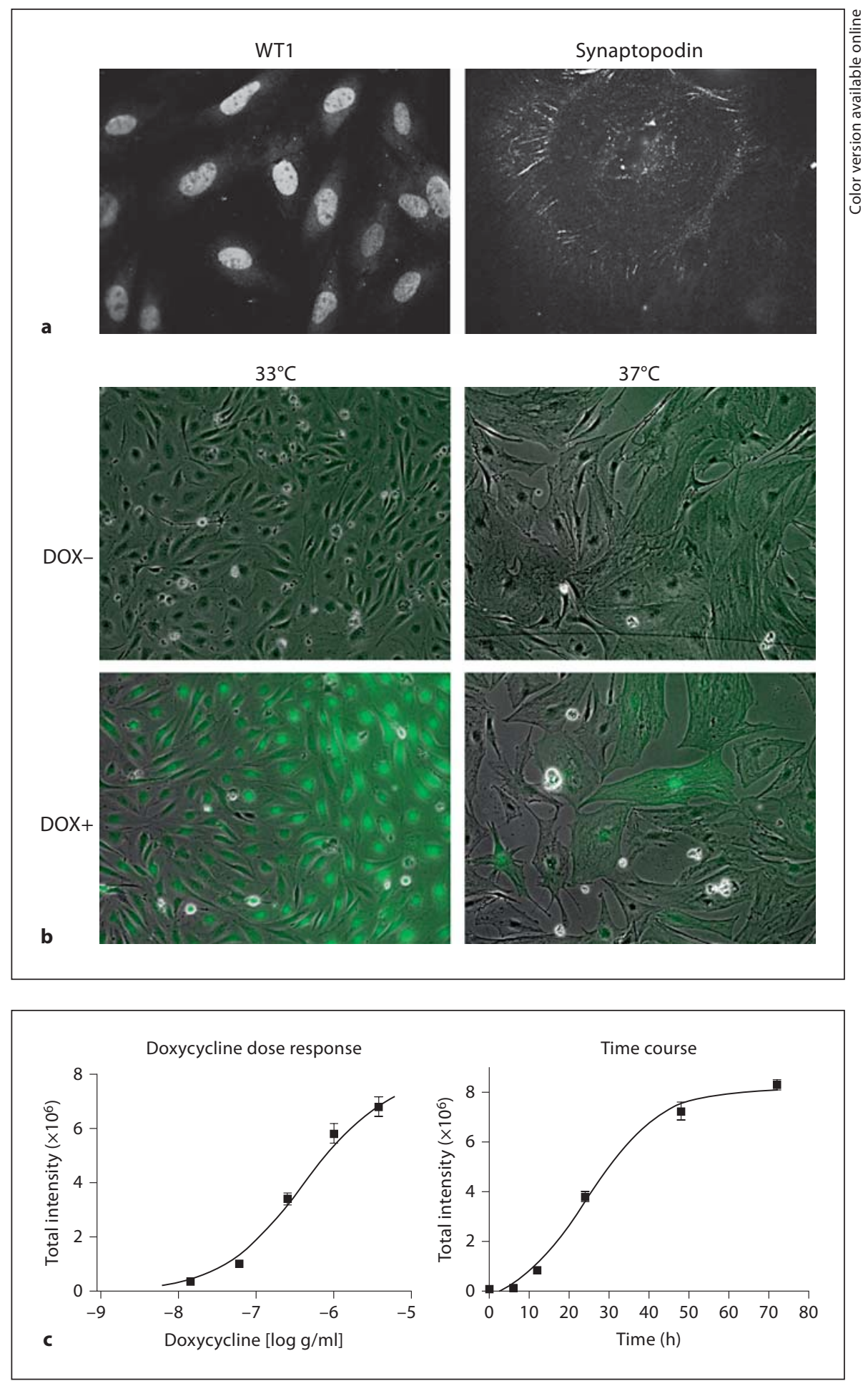

\section{Characterization of AIG Podocytes}

Sixteen AIG podocyte clones were obtained by hygromycin selection of AI podocytes transfected with pBIEGFP and SV40-Hygro. Two AIG clones manifested in- ducible EGFP expression $48 \mathrm{~h}$ after $1 \mu \mathrm{g} / \mathrm{ml}$ doxycycline treatment (fig. 2b). In these doxycycline-treated AIG podocytes cultured at $33^{\circ} \mathrm{C}$, most podocytes expressed EGFP at a high level (the apparently higher intensity of 


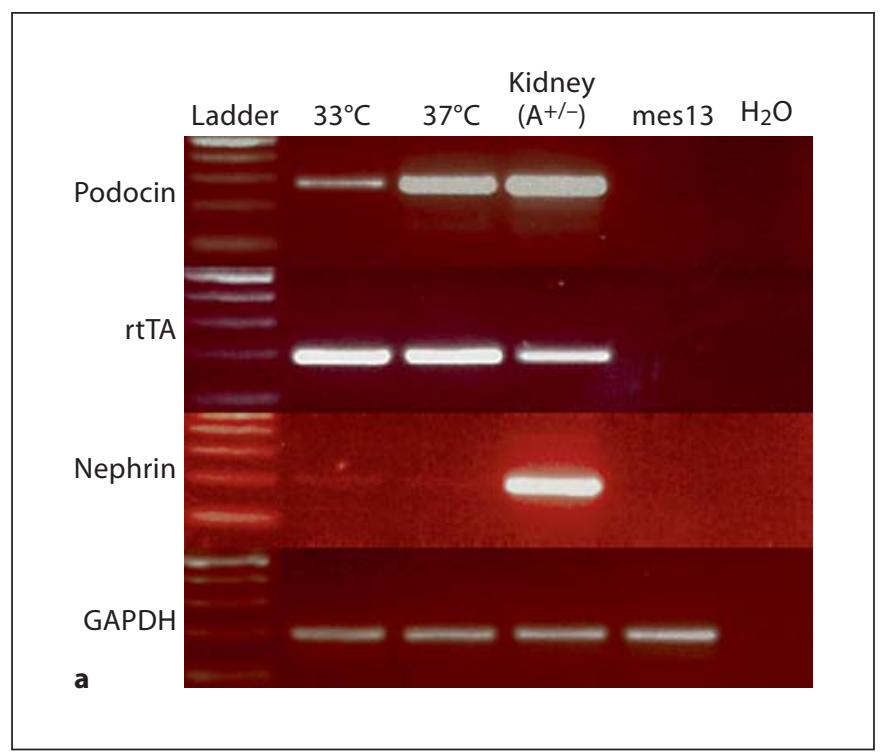

Fig. 3. Podocyte marker expression and temperature-dependent growth regulation in AIG podocytes. a NPHS2 (podocin), rtTA and NPHS1 (nephrin) mRNA were assessed in AIG podocytes by RT-PCR. As expected podocin $m R N A$ was more abundant in differentiated podocytes $\left(37^{\circ} \mathrm{C}\right)$ compared to undifferentiated podocytes $\left(33^{\circ} \mathrm{C}\right)$. Unexpectedly, rtTA was expressed equally in undifferentiated and differentiated podocytes, despite being driven by the NPHS2 promoter. The positive control for all three genes was

the right side of the field is an optical artifact). Unexpectedly, EGFP intensity was lower and more heterogeneous in podocytes cultured at $37^{\circ} \mathrm{C}$. Doxycycline-induced EGFP expression was observed in a time-dependent and doxycycline concentration-dependent manner (shown for $33^{\circ} \mathrm{C}$ podocytes; fig. $2 \mathrm{c}$ ). Time- and doxycycline concentration-dependent EGFP expression was not quantifiable at $37^{\circ} \mathrm{C}$ since the Acumen cytometer could not distinguish autofluorescence and low signal from induced EGFP. AIG podocytes retained expression of podocin and rtTA mRNA, but nephrin mRNA expression was low both at 33 and $37^{\circ} \mathrm{C}$ (fig. 3a). Temperature-dependent cell growth was maintained (fig. 3b).

\section{Characterization of AIT and AITLG Podocytes}

In the absence of doxycycline there was low-level EGFP expression, as is typical with tetracycline-inducible transgene expression which includes cytomegalovirus promoter elements. Although the EGFP signal was not obvious in the AIG podocytes of figure $2 \mathrm{~b}$ in the absence of doxycycline, we did observe leaky EGFP expression of AIG podocytes after increased exposure to the digital

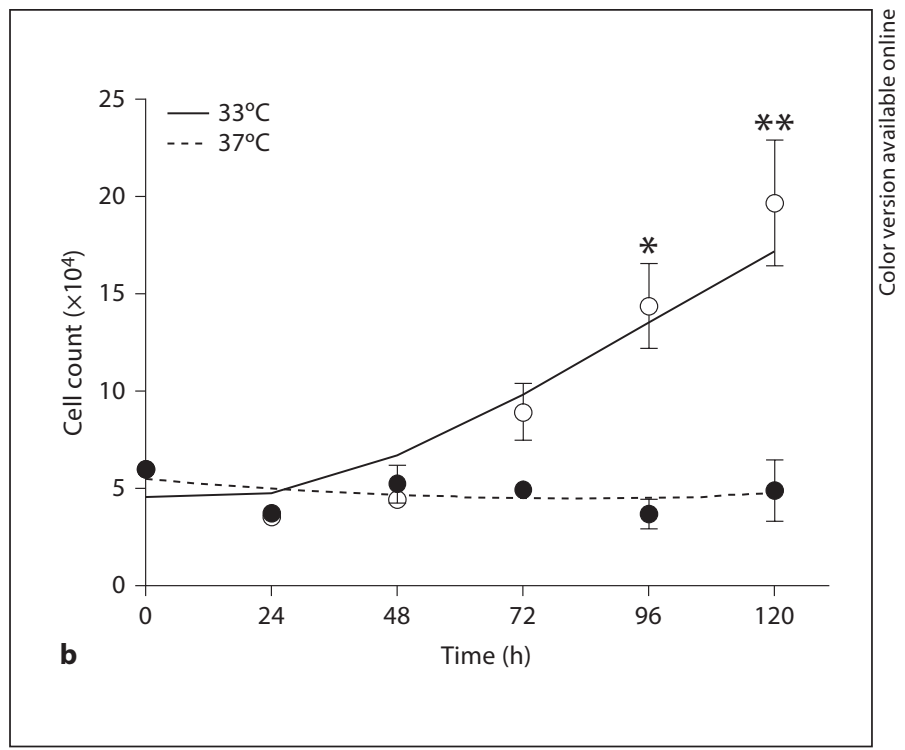

glomeruli from $\mathrm{A}^{+/-}$mice. Negative controls included mouse mesangial cells (mes13) and water. GAPDH RNA served as a loading control. b AIG podocytes were plated on collagen 1-coated 6-well plates, and cultured for the indicated time intervals. AIG podocytes proliferated when cultured at $33^{\circ} \mathrm{C}$, and ceased proliferation soon after the shift to $37^{\circ} \mathrm{C}$ (mean $\pm \mathrm{SD}, \mathrm{n}=3$ ). ${ }^{*} \mathrm{p}<0.05$ and ${ }^{* *} \mathrm{p}<0.01$ by two-way ANOVA with Bonferroni post-testing, comparing cell numbers at 33 and $37^{\circ} \mathrm{C}$.

camera (data not shown). To reduce this leakiness, AI podocytes were stably transfected with ptTS-Neo coding tetracycline-controlled transcriptional suppressor (tTS; fig. 1) [10]. Of 7 AIT clones, one was chosen based on high-level tTS mRNA expression (data not shown). Luciferase-subcloned pBI-EGFP was transiently transfected into AIT podocytes in order to compare background and induced gene expression between AI podocytes and AIT podocytes. pBI-EGFP has a bidirectional TRE element, which enables bidirectional inducible expression of luciferase and EGFP in this case (fig. 1).

In the absence of doxycycline, fewer GFP-positive cells and less luciferase activity were observed in AIT podocytes than AI podocytes (fig. $4 \mathrm{a}, \mathrm{b}$ ), as expected. The leakiness, which was calculated by dividing basal relative light units (RLU) in the absence of doxycycline by RLU in the medium without cells, was significantly lower in AIT cells compared to AI cells: $3.5 \pm 1.2$ versus $47.3 \pm$ 2.7 ( $\mathrm{p}<0.001$; fig. $4 \mathrm{c}$, left panel). Inducibility, which was calculated by dividing induced RLU with basal RLU, was significantly higher in AIT cells than AI cells: $86.7 \pm 9.6$ versus $8.7 \pm 1.4(\mathrm{p}<0.001$; fig. $4 \mathrm{c}$, right panel $)$. 


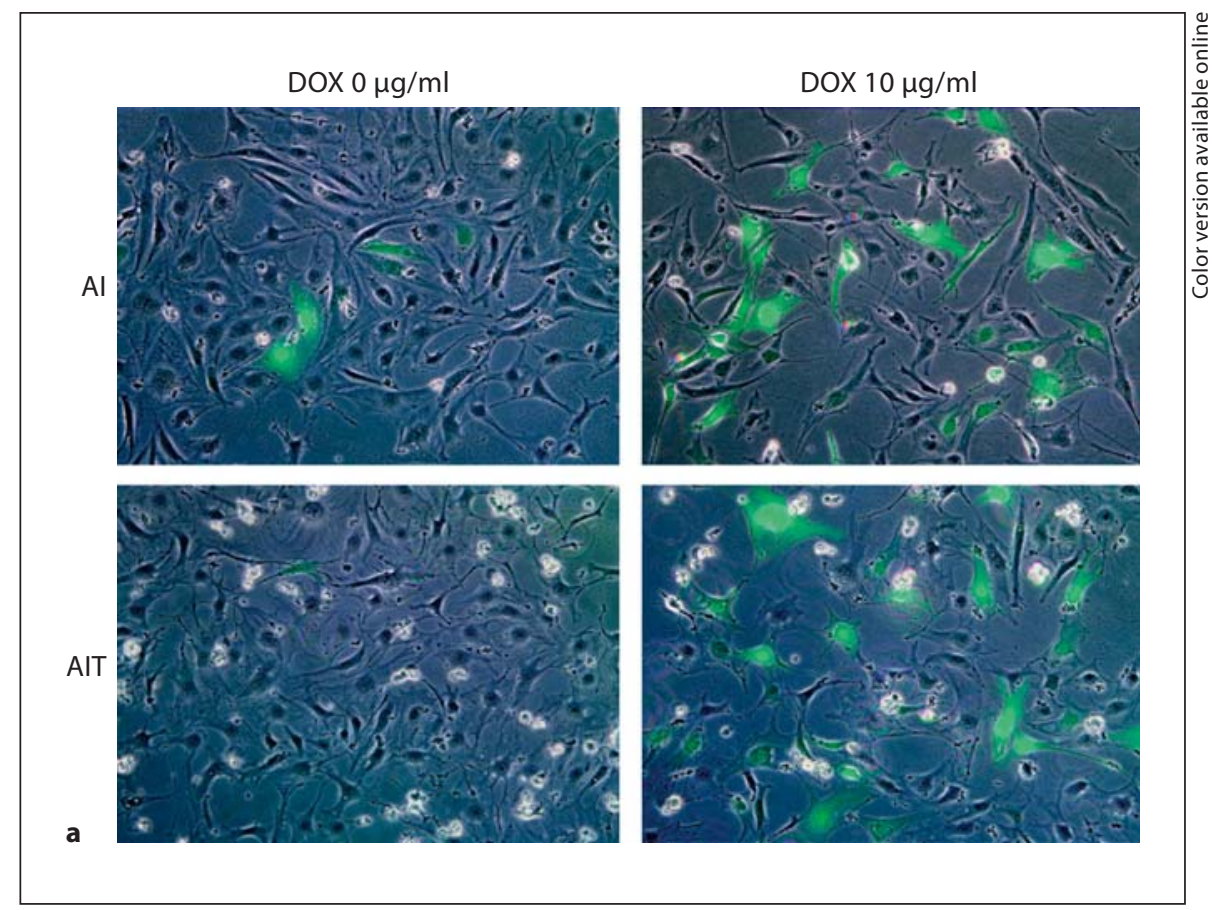

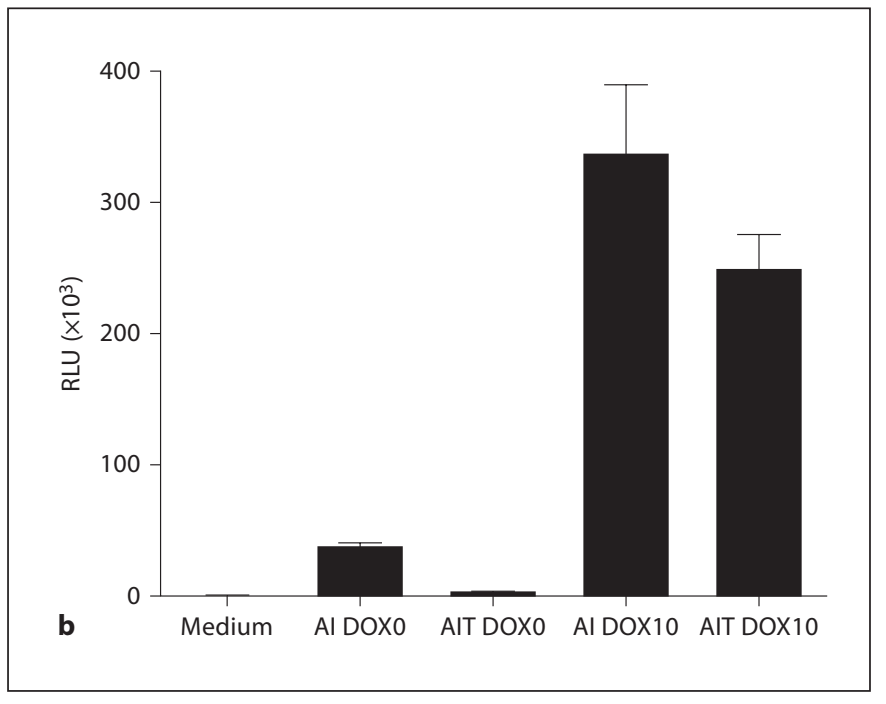

Fig. 4. Comparison of leakiness and inducibility in AI and AIT podocytes at $33^{\circ} \mathrm{C}$. AI and AIT podocytes were transiently transfected with Gaussia luciferase-pBI-EGFP, with or without doxycycline (DOX) treatment at $10 \mu \mathrm{g} / \mathrm{ml}$ for $48 \mathrm{~h}$. Gaussia luciferasepBI-EGFP has a bidirectional tetracycline-responsive element flanked by minimal CMV promoter, and both EGFP and luciferase expression are induced by DOX treatment. a Merged phase contrast image and fluorescence image showed fewer EGFP-positive cells in AIT podocytes than AI podocytes in the absence of doxycycline. Thus tTS expression has successfully reduced transgene expression in the absence of DOX. With DOX treatment, the number of EGFP expression cells was similar between AI and AIT, as expected; this also indicates equivalent transfection effi-

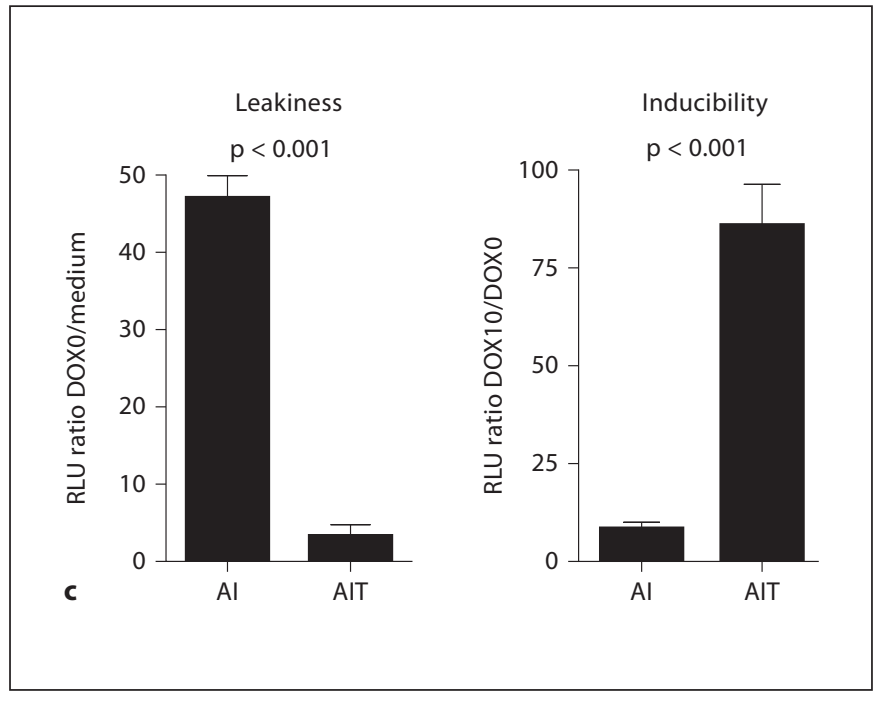

ciency. b Luciferase activity was measured in AI and AIT podocytes with or without 48 -hour DOX treatment at $10 \mu \mathrm{g} / \mathrm{ml}$ to quantify background and induced expression. $\mathbf{c}$ In the prior experiment, leakiness was calculated by dividing basal relative light units (RLU) with the mean value of RLU in medium without cells. Relative inducibility was calculated by dividing induced RLU with the mean value of basal RLU. Compared to AI podocytes, leakiness was significantly less in AIT podocytes: AIT $3.5 \pm 1.2$ versus AI $47.3 \pm 2.7$ (mean $\pm \mathrm{SD}, \mathrm{n}=3, \mathrm{p}<0.001)$. Compared to AI podocytes, AIT manifested significantly higher relative inducibility: AIT 86.7 \pm 9.6 versus AI $8.7 \pm 1.4$ (mean $\pm S D, n=3$, $\mathrm{p}<0.001)$. 


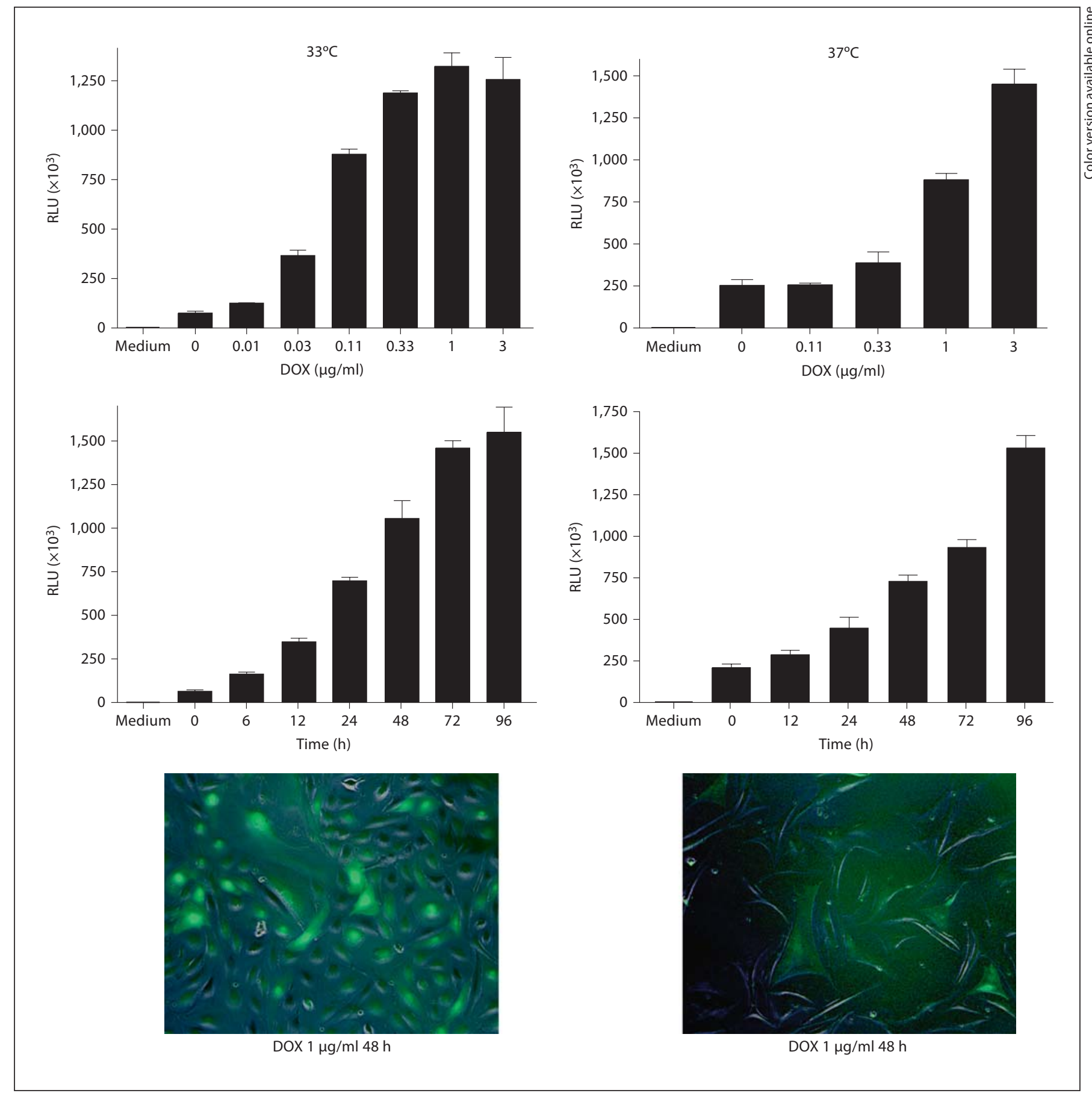

Fig. 5. Concentration- and time-dependent induction of luciferase in AITLG podocytes. AITLG podocytes were plated in collagen 1-coated 24 -well plates, cultured at $33^{\circ} \mathrm{C}$ (left column) and $37^{\circ} \mathrm{C}$ (right column), and treated with doxycycline (DOX) at dose ranges of $0-3 \mu \mathrm{g} / \mathrm{ml}$ for $48 \mathrm{~h}$, at $1 \mu \mathrm{g} / \mathrm{ml}$ for the indicated time interval ranges of $0-96 \mathrm{~h}$. Luciferase activity was measured separately under two different conditions, 33 and $37^{\circ} \mathrm{C}$, and therefore the relative light unit (RLU) values from each condition are not comparable. Inducibility and leakiness of transgene expression were calculated as described in the legend to figure 4 using the RLU value in dose-ranging study. Transgene inducibility after $48 \mathrm{~h}$ of $1 \mu \mathrm{g} / \mathrm{ml}$ DOX treatment was less in differentiated podocytes: $18.1 \pm 1.0$ at $33^{\circ} \mathrm{C}$ versus $3.5 \pm 0.1$ at $37^{\circ} \mathrm{C}(\mathrm{p}<0.001)$. Similarly, transgene leakiness, in the absence of DOX, was less in differentiated podocytes, although the difference only approached statistical significance: $421.5 \pm 64.5$ at $33^{\circ} \mathrm{C}$ versus $316.3 \pm 40.0$ at $37^{\circ} \mathrm{C}(\mathrm{p}=0.07)$. Data are presented as mean \pm SD $(n=3)$. The fluorescent image was obtained $48 \mathrm{~h}$ after DOX treatment at $1 \mu \mathrm{g} / \mathrm{ml}$ at 33 and $37^{\circ} \mathrm{C}$. Expression of EGFP was reduced and was more heterogeneous at 37 compared to $33^{\circ} \mathrm{C}$. Magnifications $\times 100$. 


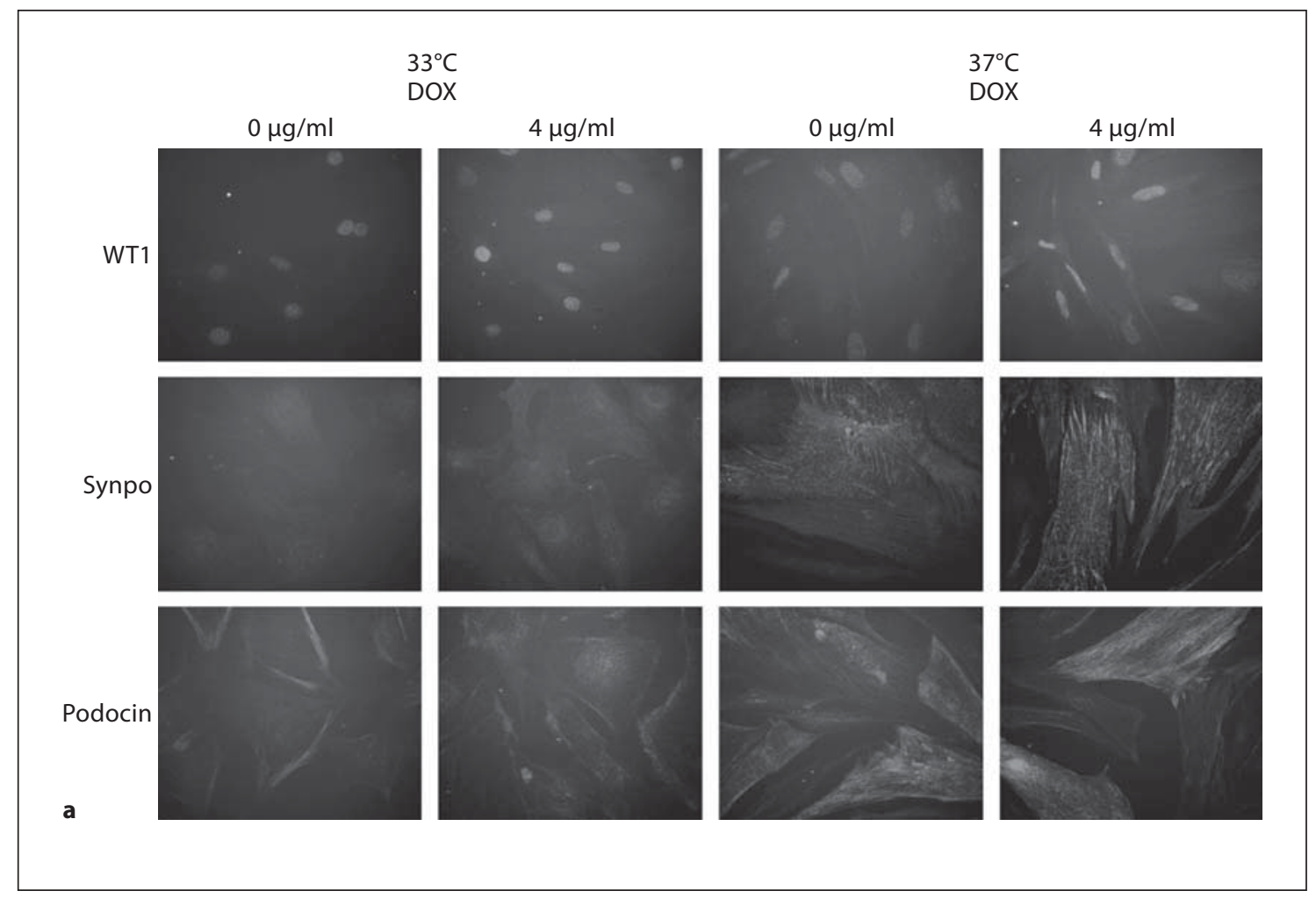

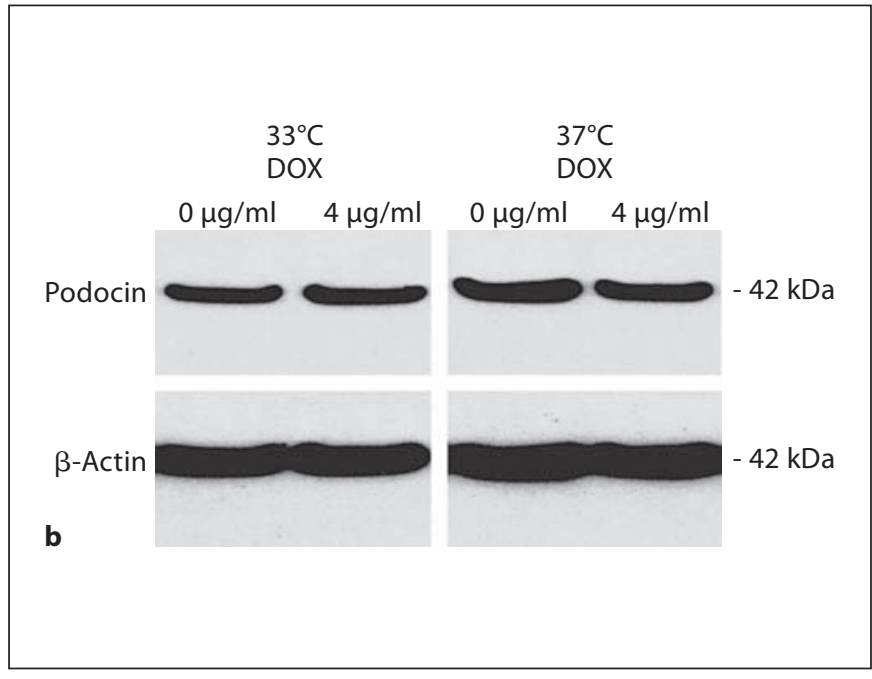

Fig. 6. Podocyte marker expression and temperature-dependent growth regulation in AITLG podocytes. AITLG podocytes were plated in collagen 1 -coated $100-\mathrm{mm}$ plates and cultured at 33 and $37^{\circ} \mathrm{C}$ with or without doxycycline (DOX) $4 \mu \mathrm{g} / \mathrm{ml}$ for $48 \mathrm{~h}$. a WT1, synaptopodin (Synpo) and podocin were localized by indirect immunofluorescence. WT1 was expressed similarly at 33 and $37^{\circ} \mathrm{C}$, and synaptopodin and podocin were expressed more abundantly in differentiated podocytes $\left(37^{\circ} \mathrm{C}\right)$. Expression for these proteins was unaffected by DOX treatment. Magnification

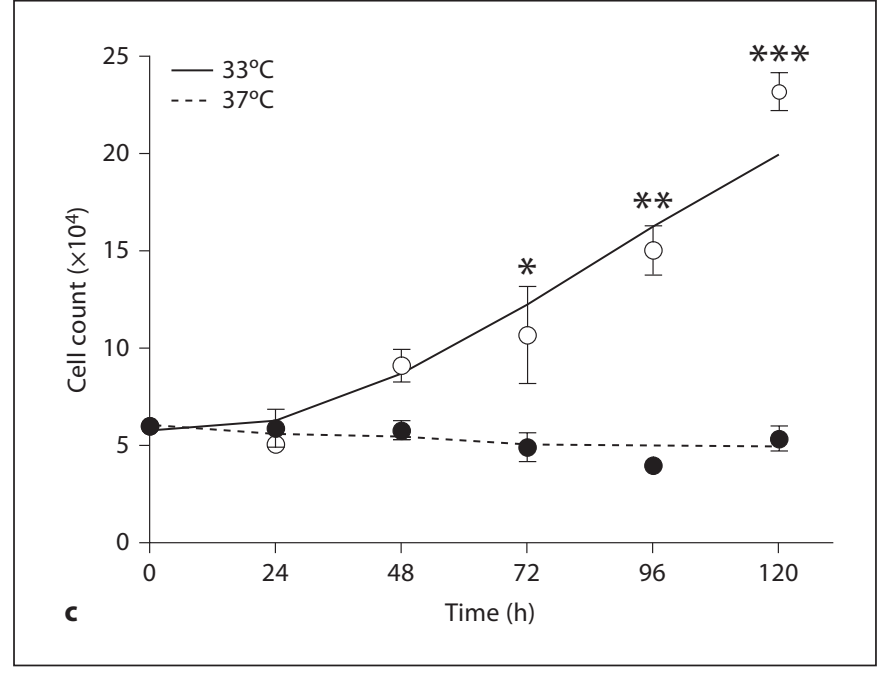

$\times 100$. $\mathbf{b}$ Cell pellets were lysed with CHAPS buffer and subjected to Western blotting for podocin, with $\beta$-actin serving as loading control. Podocin expression was greater at $37^{\circ} \mathrm{C}$ and unaffected by DOX treatment. c AITLG podocytes were plated on collagen 1-coated 6-well plates, and cultured for the indicated time intervals. AITLG podocytes proliferated when cultured at $33^{\circ} \mathrm{C}$, while they ceased proliferating soon after shift to $37^{\circ} \mathrm{C}$. Data are presented as mean $\pm \mathrm{SD}(\mathrm{n}=3) .{ }^{*} \mathrm{p}<0.05 ;{ }^{* *} \mathrm{p}<0.01$; ${ }^{* * *} \mathrm{p}<$ 0.001 . 
In order to prove quantifiable regulation of gene expression at the non-permissive temperature, we stably transfected AIT podocytes with the luciferase-pBI-EGFP construct to generate AITG podocytes. After hygromycin selection, 44 clones were harvested and only one clone was found to express both EGFP and luciferase. This AITLG cell line showed time-dependent and doxycycline concentration-dependent induction of luciferase expression under both permissive and non-permissive conditions (fig. 5). When cultured at $37^{\circ} \mathrm{C}$, the AITLG podocytes exhibited reduced EGFP expression and more heterogeneity among cells (fig. 5, bottom panels), as had been seen in AIG podocytes (fig. 2b). This finding was consistent with lower inducibility at $37^{\circ} \mathrm{C} 48 \mathrm{~h}$ after $1 \mu \mathrm{g} / \mathrm{ml}$ doxycycline treatment, $18.1 \pm 1.0$ at $33^{\circ} \mathrm{C}$ versus $3.5 \pm 0.1$ at $37^{\circ} \mathrm{C}(\mathrm{n}=3, \mathrm{p}<0.001)$. Interestingly, leakiness was somewhat less in AITLG podocytes at $37^{\circ} \mathrm{C}$ compared to $33^{\circ} \mathrm{C}: 421.5 \pm 64.5$ at $33^{\circ} \mathrm{C}$ versus $316.3 \pm 40.0$ at $37^{\circ} \mathrm{C}(\mathrm{n}=3, \mathrm{p}=0.07)$.

Despite repeated passages after two stable transfections, AITLG podocytes retained podocyte markers at passage 22, including expression of WT1, synaptopodin and podocin. As expected, synaptopodin and podocin were expressed more abundantly at $37^{\circ} \mathrm{C}$ compared to $33^{\circ} \mathrm{C}$ (fig. 6a). Podocyte marker expression was unaffected by $4 \mu \mathrm{g} / \mathrm{ml}$ doxycycline treatment (fig. 6a, b). Cell growth regulation was also maintained in a temperaturedependent manner in AITLG podocytes (fig. 6c).

\section{Discussion}

We have described a system of regulated gene expression in conditionally immortalized mouse podocytes. We confirmed that expression was induced after doxycycline treatment at both 33 and $37^{\circ} \mathrm{C}$ in a time-dependent and doxycycline concentration-dependent manner, while preserving podocyte differentiation markers and temperature-sensitive growth regulation.

This cell culture system offers important advantages for future podocyte studies. First, almost all stably transfected podocytes expressed the gene of interest both at 33 and $37^{\circ} \mathrm{C}$, although heterogeneity in induction could be seen at $37^{\circ} \mathrm{C}$. Second, this inducible system offers the opportunity for precise quantitative control over transgene expression in both undifferentiated and differentiated podoctyes, as we have demonstrated. With this tool, it is possible to study the effect of overexpression or knockdown of various cell proteins, including transcription factors, intracellular signaling molecules, adhesion molecules, membrane channels and transporters, extracellular matrix molecules, viral proteins, and others.

Our system currently has several important limitations that will require further development to address. First, some background transgene expression remains in the absence of inducer. The use of the tTS transgene reduced but did not entirely eliminate this leakiness. This limitation may make it difficult to obtain stable transfectants with toxic genes. It is possible that the introduction of the transgenes into particular chromosomal locations may affect the level of leakiness, and particular transfectants may avoid this problem. Second, we observed lower transgene inducibility at nonpermissive conditions $\left(37^{\circ} \mathrm{C}\right)$ compared to permissive conditions $\left(33^{\circ} \mathrm{C}\right)$. The reasons for this observation are not entirely clear, as the use of the NPHS 2 promoter to drive rtTA expression was expected to produce the opposite effect. We speculate that the tetracycline-inducible system itself could be affected by differentiation status, at least in podocytes relying on the NPHS2 promoter to drive transgene expression, as we also observed reduced doxycycline-induced EGFP expression in AIG podocytes treated with differentiation inducers such as all-trans retinoic acid or 1,25(OH)-vitamin D (data not shown).

Despite these limitations, we believe that these murine podocyte cell lines may be useful to other investigators working on various aspects of podocyte cell biology.

\section{Acknowledgments}

This work was supported by the Intramural Research Program, NIDDK, NIH and the Japanese Society for the Promotion of Science Research Fellowship for Japanese Biomedical and Behavioral Researchers at NIH. We thank Dr. Katsuhiko Asanuma and Dr. Peter Mundel for valuable advice on podocyte culture and for providing antibodies. Also, we thank Dr. Peter Yuen for critical review of the manuscript. Part of this work was presented at the 2006 annual meeting of the American Society of Nephrology in San Diego, Calif., USA. 


\section{References}

1 Shankland SJ: The podocyte's response to injury: role in proteinuria and glomerulosclerosis. Kidney Int 2006;69:2131-2147.

2 Mundel P, Reiser J, Zuniga Mejia Borja A, Pavenstadt H, Davidson GR, Kritz W, Zeller R: Rearrangements of the cytoskeleton and cell contacts induce process formation during differentiation of conditionally immortalized mouse podocyte cell lines. Exp Cell Res 1997;236:248-258.

$\checkmark 3$ Saleem MA, O’Hare MJ, Reiser J, Coward RJ, Inward CD, Farren T, Xing CY, Ni L, Mathieson PW, Mundel P: A conditionally immortalized human podocyte cell line demonstrating nephrin and podocin expression. J Am Soc Nephrol 2002;13:630-638.
-4 Shankland SJ, Pippin JW, Reiser J, Mundel P: Podocytes in culture: past, present, and future. Kidney Int 2007;72:26-36.

5 Urlinger S, Baron U, Thellmann M, Hasan MT, Bujard H, Hillen W: Exploring the sequence space for tetracycline-dependent transcriptional activators: novel mutatins yield expanded range and sensitivity. Proc Natl Acad Sci USA 2000;97:7963-7968.

-6 Shigehara T, Zaragoza C, Kitiyakara C, Takahashi H, Lu H, Moellar M, Holtzman LB, Kopp JB: Inducible podocyte-specific gene expression in transgenic mice. J Am Soc Nephrol 2003; 14:1998-2003.
7 Jat PS, Noble MD, Ataliotis P, Tanaka Y, Yannoutsos N, Larsen L, Kioussis D: Direct derivation of conditionally immortal cell lines from an $\mathrm{H}-2 \mathrm{~Kb}$-tsA58 transgenic mouse. Proc Natl Acad Sci USA 1991;88: 5096-5100.

8 Misra RP: Isolation of glomeruli from mammalian kidneys by graded sieving. Am J Clin Pathol 1972;58:135-139.

$\checkmark 9$ Fan Q, Ding J, Zhang J, et al: Effect of the knockdown of podocin mRNA on nephrin and alpha-actinin in mouse podocyte. Exp Biol Med (Maywood) 2004;229:964-970.

10 Freundlieb S, Schirra-Muller C, Bujard H: A tetracycline controlled activation/repression system with increased potential for gene transfer into mammalian cells. J Gene Med 1999; 1:4-12. 